JRSSEM 2021, Vol. 01, No. 4, $401-408$

E-ISSN: 2807 - 6311, P-ISSN: 2807 - 6494

\title{
CAROTENE REDUCTION LEVEL IN THE PROGESSING OF PUMPKIN INSTANT BROWNIES
}

\author{
Silvia Oktavia Nur Yudiastuti ${ }^{1^{*}}$ \\ Agung Wahyono ${ }^{2}$ \\ Yani Subaktilah ${ }^{3}$ \\ ${ }^{1,2}$ Food Engineering, Politeknik Negeri Jember, Indonesia \\ ${ }^{3}$ Food Industrial Technology, Politeknik Negeri Jember, Indonesia \\ e-mail: silvia.oktavia@polije.ac.id \\ *Correspondence: silvia.oktavia@polije.ac.id
}

Submitted: 30 September 2021, Revised: 8 November 2021, Accepted: 14 November 2021

\begin{abstract}
Pumpkin is a local food of Jember which the amount of harvested area and productivity is increasing every year. Pumpkin is a source of beta carotene with a relatively lower price than other beta carotene sources. Diversification of pumpkin-based food products will produce nutritionally rich products with added value. Brownies are one of the bakery products that can be processed with $100 \%$ pumpkin flour as raw material, increasing the added value can be done by diversifying it into semi-finished products with pumpkin steamed brownie premix flour. The objective was evaluated carotene level changes as its functional component in the diversification process. The research method used was descriptive evaluating changes in carotene in 6 treatments of pumpkin steamed brownies premix flour formulations. Based on the results of the study, the most abundant carotene was found in the $100 \%$ pumpkin flour formulation treatment, namely $77.99 \mathrm{mg} / 100 \mathrm{~g}$ in premix flour and $5.05 \mathrm{mg} / 100 \mathrm{~g}$ in steamed brownies. The higher the pumpkin content, the lower the degree of reduction in total carotene will be.
\end{abstract}

Keywords: brownies; carotene; functional properties; local food; pumpkin. 


\section{INTRODUCTION}

According to FAO, local food is food that is produced, marketed and consumed by local or local communities. Meanwhile, according to Law No. 18 of 2012, local food is food consumed by the local community according to local potential and wisdom. Based on this, local food refers to food that optimizes local resources that were previously consumed for generations by the local community both in fresh form and processed into local specialties (UU No 18 Tahun 2012 Tentang Pangan, 2012) One of the reasons for consuming local food is food safety and quality as well as the impact on the environment because local food has a close distribution distance. Local food should be positioned as part of the national food system because it has the potential to achieve food security, fulfill nutrition and drive the local rural economy. One of the efforts made by the government in including local food in the national food system is to encourage the cultivation of local foods and food product diversification based on local food ingredients (UU No 18 Tahun 2012 Tentang Pangan, 2012).

Pumpkin is one of the local plants in East Java whose harvested area, production and productivity continues to increase every year. In order to diversify local food products made from pumpkin, various studies have been carried out on processing pumpkin into semi-finished and ready-to-eat food. These products include pumpkin flour and various processed bakery products that were commonly consumed by the surrounding community (Indriyanti et al., 2017; Nuraliza \& Fadilah, 2016; C. . Nurjanah et al., 2017; N. Nurjanah
\& Usmiati, 2006; Pramudito \& Salim, 2020).

However, no study has been carried out in the production of premix flour for bakery products. Based on its characteristics, pumpkin flour cannot trap gas in the dough, so the bacterial product that is more suitable to be developed with pumpkin flour raw materials is brownies. Brownies are a type of non-expands chocolate bakery but has a moist inner texture, dry top textured, and has a sweet taste and a distinct chocolate aroma.

Pumpkin is a source of beta carotene with an amount of $1.18 \mathrm{mg} / 100 \mathrm{~g}$ $2.25 \mathrm{mg} / 100 \mathrm{~g}$ (de Carvalho et al., 2012, 2014; Milani et al., 2017; Toan et al., 2018). Beta carotene is one type of carotenoids, apart from being provitamin- $A$, beta Carotenoids also act as antioxidants effective at low oxygen concentrations. Some of the properties of beta carotene include being fat-soluble, soluble in nonpolar and semi-polar solvents, and sensitive to free air oxidation (Priyadarshani, 2017). Among these properties, there has not been a study on the effect of heat processing on betacarotene where in general food processing processes for diversification of processed pumpkin products using heat include pasteurization, steaming, boiling, or roasting temperatures. In terms of pumpkin diversification into pumpkin brownie premix flour, heat processing was carried out in the manufacture of flour, as well as heat processing when steaming the brownies (Toan et al., 2018). 


\section{METHODS}

The research was conducted in August - December 2020 at the Food Processing Laboratory of Politeknik Negeri Jember and test laboratory of the Agricultural Technology Faculty of Universitas Gajah Mada. The study began with preliminary research in determining the formulation and method of making pumpkin steamed brownies until six treatments were produced which were variations in the ratio of substituted wheat flour with pumpkin flour. The tools used in this research are basin, egg beater, food dehydrator, grinder, incubator, desiccator, furnace, porcelain dish, aluminum cup, socket, kjeldhal flask, RVA, texture analyzer. The materials used were local varieties of Jember pumpkin, ant sugar, wheat flour, eggs, palm oil, margarine, baking powder, filter paper, Vaseline, silica gel, $50 \% \mathrm{NaOH}$, $4 \% \mathrm{~K} 2 \mathrm{SO} 4, \mathrm{PP}$ indicator, concentrated $\mathrm{H} 2 \mathrm{SO} 4$, selenium, $\mathrm{HgO} 2,2 \%$ boric acid, hexane and distilled water. The study was conducted using a descriptive explanatory research method consisting of six treatment wheat flour and pumpkin flour comparison which is presented in Table 1 (Wahyono et al., 2020).

Table 1. Design of Experiment

\begin{tabular}{ccccccc}
\hline Ingredients & BR01 & BR11 & BR12 & BR13 & BR14 & BR15 \\
\cline { 2 - 7 } Wheat Flour $(\mathbf{g})$ & 100 & 80 & 60 & 40 & 20 & 0 \\
\hline Pumpkin Flour (g) & 0 & 20 & 40 & 60 & 80 & 100 \\
\hline Powder Milk (g) & 65 & 65 & 65 & 65 & 65 & 65 \\
\hline Powdered sugar (g) & 48 & 48 & 48 & 48 & 48 & 48 \\
\hline Baking powder (g) & 6 & 6 & 6 & 6 & 6 & 6 \\
\hline Palm oil (g) & 50 & 50 & 50 & 50 & 50 & 50 \\
\hline Margarine (g) & 50 & 50 & 50 & 50 & 50 & 50 \\
\hline Whole egg (g) & 110 & 110 & 110 & 110 & 110 & 110 \\
\hline
\end{tabular}

Source: (Wahyono et al., 2020)

\section{The Production of Pumpkin Flour}

$20 \mathrm{~kg}$ of local Jember pumpkin was peeled and removed the seeds and matrix. Furthermore, the pumpkin was washed using tap water and sliced with a thickness of $2 \mathrm{~cm}$. The pumpkin was soaked in $0.2 \%$ sodium metabisulfite for 23.05 minutes. The pumpkin was then drained and dried at $85 \mathrm{C}$ for 11.4 hours using a food dehydrator. Dried pumpkin was ground using a grinder and sieved at 80 mesh size (Wahyono et al., 2018).

\section{Pumpkin Brownie Premix Flour Production}

The first dough mix was wheat flour and pumpkin flour according to the treatment. The second dough mix was powdered sugar, milk powder, and baking powder before adding to the first mix. The first and second mixes were then stirred until evenly distributed and put in an airtight container (Subaktilah, Wahyono, Yudiastuti, \& Mahros, 2021). 


\section{Pumpkin Steamed Brownie Production}

whisk together the eggs and palm oil in a large bowl, it was called wet ingredients. Pour wet ingredients into dry mix of pumpkin steamed brownie premix flour, stirred well. Pour melted margarine into the mix and fold until just combined. The batter will be thick. Then, pour the batter into an $8 \times 8$ inch baking pan lined with parchment paper. Use a rubber spatula to spread it to all four sides of the pan and to smooth the top. The mixture will be very thick. Transfer the pan into a steaming pot and steam for 40 to 45 minutes, until a toothpick inserted comes out with a few crumbs attached. Allow the brownies to cool completely before slicing and serving.

\section{Carotene Analysis}

The emulsion product is weighed as much as 0.1 grams and put into a $25 \mathrm{~mL}$ volumetric flask, then the sample is dissolved with hexane until mark, by shaking until completely homogeneous. The Sample absorbance was measured at a wavelength of $446 \mathrm{~nm}$ using Spectrophotometry. Furthermore, the total carotenoid value is calculated using the following equation:

$$
\mathrm{T}=\frac{25 \times A \times 383}{100 \times W}
$$

$\mathrm{T}=$ total carotenoids;

$A=$ Absorbance at a wavelength of $446 \mathrm{~nm}$;

$\mathrm{W}=$ Weight of sample (grams)

\section{RESULTS AND DISCUSSION}

The pumpkin flour used in this study was made from fresh local Jember pumpkin purchased from local farmers. The process of making pumpkin flour was carried out using a previously optimized method to produce pumpkin flour with the best antioxidant content. Processing of fresh pumpkin into pumpkin flour is part of the preliminary research conducted in this study. The total carotene content of pumpkin flour produced as the raw material for this research was then compared with commercial pumpkin flour that has been circulating in the market. The total carotene results analysis of the content are presented in Table 2.

Table 2. Carotene in Pumpkin Flour

\begin{tabular}{lc}
\hline \multicolumn{1}{c}{ Pumkin Flor } & $\begin{array}{c}\text { Caroteen } \\
\text { (mg/100gr) }\end{array}$ \\
\hline \multicolumn{2}{c}{ Commercial pumpkin } \\
Flour \\
\hline \multicolumn{2}{c}{ Used in the research } \\
$\begin{array}{l}\text { Source: Research Laboratory } \\
\text { Result, } 2020\end{array}$ & analysis \\
\end{tabular}

The total carotene content in pumpkin flour used in this study was 4 times higher than the flour that has been commercialized in the market. Based on the analysis of the results, it is expected that the total carotene content in brownies will not decrease drastically.

Preliminary experiments, previously also carried out on the process to get ingredients composition of pumpkin steamed brownies with minimal taste and texture, which refers to research that examines the formulation of brownies with sweet potato flour as raw material. The advantage of pumpkin brownies produced in this study is that they do not use chocolate like brownies in general. This is 
intended to produce brownies with a strong pumpkin taste and aroma as its advantages.

The product produced in this study is actually a semi-finished product ready to be processed which is pumpkin steamed brownies premix flour, but to ensure product quality that will be accepted by consumers, testing was also carried out on the final product that will be consumed by consumers, namely, pumpkin steamed brownies. So that the total carotene test was carried out both on pumpkin flour as a raw material for the product, premix flour which will be processed by consumers, and steamed pumpkin brownies which will be consumed by consumers. The results analysis of total carotene in premix flour and pumpkin steamed brownies are presented in the figure 1

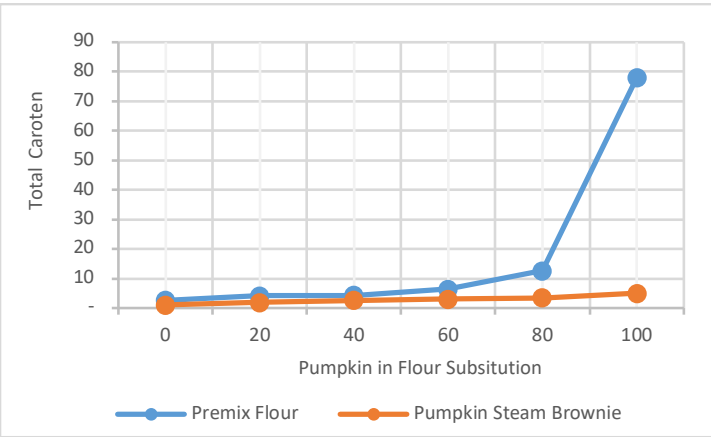

Figure. 1: Total Carotene in Premix Flour and Steam Brownies

Based on Figure 1, the more comparisons of pumpkin flour in the product formulation, the higher the total carotene content in the product. A very significant difference is shown in the formulation of pumpkin steamed brownies using $100 \%$ pumpkin flour in its formulation. The total carotene content in the product is as follows:
1. Formulation of $0 \%$, is $2.59 \mathrm{mg} / 100 \mathrm{gr}$ in premix flour and $1.1 \mathrm{mg} / 100 \mathrm{~g}$ in steamed brownie product.

2. Formulation of $20 \%, 4.12 \mathrm{mg} / 100 \mathrm{gr}$ in premix flour and $1.8 \mathrm{mg} / 100 \mathrm{~g}$ in steamed brownie product.

3. Formulation of $40 \%, 4.42 \mathrm{mg} / 100 \mathrm{gr}$ in premix flour and $2.64 \mathrm{mg} / 100 \mathrm{~g}$ in steamed brownie products

4. Formulation of $60 \%, 6.41 \mathrm{mg} / 100 \mathrm{gr}$ in premix flour and $2.98 \mathrm{mg} / 100 \mathrm{~g}$ in steamed brownie products

5. Formulation of $80 \%, 12.63 \mathrm{mg} / 100 \mathrm{gr}$ in premix flour and $3.34 \mathrm{mg} / 100 \mathrm{~g}$ in steamed brownie products

6. Formulation of $100 \%, 78.19 \mathrm{mg} / 100 \mathrm{~g}$ and $5.01 \mathrm{mg} / 100 \mathrm{~g}$ in the steamed brownie product.

Total carotene reduction is the ratio of total carotene in pumpkin steamed brownies with total carotene in premix flour. The data is presented in graphical form in Figure 2.

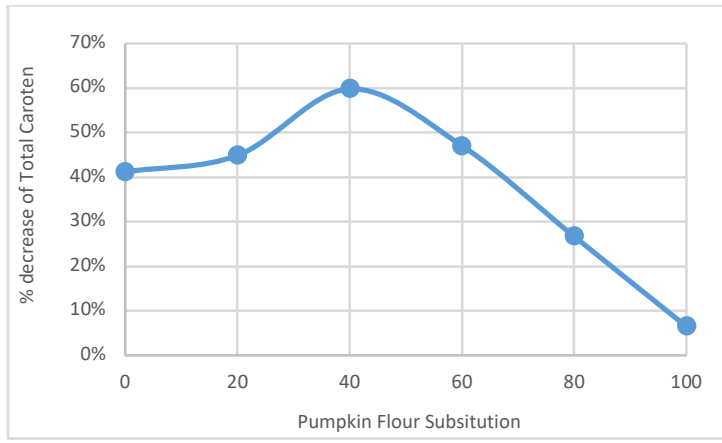

Figure. 2: Carotene Reduction in Pumpkin Steam Brownies from Pumpkin Steam Brownies Premix Flour

In the publication of the results of previous studies, it was stated that the pumpkin premix flour which had the higher nutritional value among treatment was substituted with $20 \%$ pumpkin flour 
(Subaktilah, Wahyono, Yudiastuti, \& Avianti, 2021)as well as the pumpkin steamed brownie product which was declared to have the higher nutritional value among treatment, which was substituted with $20 \%$ of pumpkin flour (Subaktilah, Wahyono, Yudiastuti, \& Mahros, 2021). However, the results were not the same as the results of the analysis of total carotene in the premix flour of instant steamed pumpkin brownies and their brownie products. From the result obtained as presented in figure 2, the higher the total carotene content in the pumpkin steamed brownie premix flour, the lower the total carotene reduction rate in the pumpkin steamed brownie product that will be processed by consumers.

according to Figure 2, the average reduction of carotene in the study was $38 \%$, namely $41 \%$ reduction in $0 \%$ treatment, $45 \%$ reduction in $20 \%$ treatment, $60 \%$ reduction in $40 \%, 47 \%$ in $60 \%$ treatment, $27 \%$ in treatment $80 \%$, and $6 \%$ at $100 \%$ treatment. Based on the carotene reduction value, it can be concluded that wheat flour has an effect on the decrease in total carotene during the making process of pumpkin steamed brownies, considering that other ingredients are added to the formulation in the same amount and the reduction rate is very small in the product formulation of $100 \%$ pumpkin flour. This result is in line with the results of previous research which states that consumers choose brownies with $100 \%$ pumpkin flour content, because they have a texture that is more like brownies and the aroma of pumpkin is very dominant (Yudiastuti et al., 2021).

Starch wheat is present in the form of small granules (1-40 m) and in a system, for example dough, flour dispersed and serves as a filler. The protein from wheat flour forms a interconnected network on dough and responsible as components that make up viscoelastic. Gluten is the main protein in wheat flour consisting of gliadin (20$25 \%)$ and glutenin (35-40\%). About 30\% Gluten amino acids are hydrophobic and these amino acids can cause proteins to clump through hydrophobic interactions and fat binding and other non-polar substances. When Wheat flour mixed with water, the parts of the protein that expand carry out hydrophobic interactions and reactions sulfydryl-disulfide exchange produce bonds like polymers. These polymers interact with other polymers through bonds hydrogen, hydrophobic and disulfide bonds cross-linking to form like sheet-like film and has the ability to bind gases trapped. In making the dough subjected to heating, gluten has ability as a material that can form adhesive (sticky properties), cohesive mass (materials can become adhesive) cohesive), films, and 3dimensional networks. The use of gluten in the bakery industry is intended to give strength to dough, capable of storing gas, forming structure and water absorption. Gluten also used for formulation purposes, binders, and fillers (Jasthi et al., 2020).

The greater the concentration of wheat flour causes most of the water to be absorbed into the starch. The addition of water into flour will cause starch absorbs water and expands. However, the amount of water absorbed and swelling phenomena were limited. The maximum water absorbed was only reach $30 \%$. When the starch granules heated, water volume 
and swelling will be increase. During the process of mixing the dough which is accompanied by heating and also continue with steaming temperature, water absorption occurs gradually. If Wheat flour was only mixed with water then the swelling of the starch granules will occur maximally, but fat from other ingredients turns out have a strong influence. When fat lumps spread between starch gel, starch can't swell naturally maximum. In the condition where the globules fat interacts with non-polar substance, fat globule will also bind the starch that swelling is not optimal. Even though according to its function which can form a matrix layer, it is expected to protect carotene during the dough processing and steaming.

\section{CONCLUSIONS}

The higher the content of pumpkin flour, the total amount of carotene in premix flour will be higher and the rate of decrease in total carotene will be lower. Wheat flour has an effect in reducing total carotene in product formulations. The increase in the addition of pumpkin flour in the formulation of pumpkin steamed brownie premix flour causes gluten to not work optimally in protecting beta carotene in the processing.

\section{REFERENCES}

De Carvalho, L. M. J., Gomes, P. B., Godoy, R. L. de O., Pacheco, S., do Monte, P. H. F., de Carvalho, J. L. V., Nutti, M. R., Neves, A. C. L., Vieira, A. C. R. A., \& Ramos, S. R. R. (2012). Total carotenoid content, $\alpha$-carotene and $\beta$-carotene, of landrace pumpkins moschata Duch): A preliminary study. Food Research International, 47(2), 337340.

https://doi.org/10.1016/j.foodres.2011. $\underline{07.040}$

de Carvalho, L. M. J., Smiderle, L. de A. S. M., de Carvalho, J. L. V., Cardoso, F. de S. N., \& Koblitz, M. G. B. (2014). Assessment of carotenoids in pumpkins after different home cooking conditions. Food Science and Technology, 34(2), 365-370.

https://doi.org/10.1590/fst.2014.0058

Indriyanti, E., Purwaningsih, Y., \& Wigati, D. (2017). skrining fitokimia dan standarisasi ekstrak kulit buah labu kuning (cucurbita moschata). Penelitian Pangan, 20-25.

Jasthi, B., Pettit, J., \& Harnack, L. (2020). Addition of gluten values to a food and nutrient database $\star$. Journal of Food Composition and Analysis, 85(March 2019),

103330. https://doi.org/10.1016/.j.jca.2019.103 $\underline{330}$

Milani, A., Basirnejad, M., Shahbazi, S., \& Bolhassani, A. (2017). Carotenoids: Biochemistry, pharmacology and treatment. Journal of Pharmacological and Toxicological Methods, 174, 12901324.

Nuraliza, A., \& Fadilah, R. (2016). Pengaruh penambahan labu kuning (Cucurbita moschata) dan ubi jalar ungu (Ipomoea batatas $\mathrm{L}$ ) terhadap kecepatan leleh es krim yang dihasilkan. Jurnal Pendidikan Teknologi Pertanian, 2, 7-13.

Nurjanah, C. ., Lubis, Y. ., \& Yusriana. (2017). Pembuatan Mie kering dari Labu Kuning (Cucurbita moschata) dengan variasi hidrokoloid. Jurnal Ilmiah 
Mahasiswa Pertanian Unsyiah, 2(3).

Nurjanah, N., \& Usmiati, S. (2006). ekstraksi dan karakterisasi pektin dari kulit labu kuning. Jurnal Pasca Panen, 3(1), 13-23.

Pramudito, \& Salim, C. (2020). Subsitusi Ubi Dengan Labu Kuning Pada Pembuatan Kue Talam. Sekolah Tinggi Pariwisata Trisakti.

UU No 18 Tahun 2012 Tentang Pangan, 66 37 (2012).

Priyadarshani, A. M. B. (2017). A review on factors influencing bioaccessibility and bioe_cacy of carotenoids. Critical Reviews in Food Science and Nutrition, 57, 1710-1717.

Subaktilah, Y., Wahyono, A., Yudiastuti, S., \& Mahros, Q. A. (2021). Pengaruh Substitusi Tepung Labu Kuning ( Cucurbita moschata L) terhadap Nilai Gizi Brownies Kukus Labu Kuning. Jurnal Ilmiah Inovasi, 21(1), 18-21.

Subaktilah, Y., Wahyono, A., Yudiastuti, S. O. N., \& Avianti, T. M. (2021). Chemical characteristic of steamed pumpkin brownies premix flour. IOP Conference Series: Earth and Enviromental Science. https://doi.org/10.1088/17551315/672/1/012054

Toan, N. Van, Thi, N., Thuy, T., Chi, H., City, M., Ward, L. T., District, T. D., Chi, H., \& City, M. (2018). Production of highquality flour and the made biscuits from Pumpkin. 157-166.

Wahyono, A., Kurniawati, E., Kasutjianingati, K., Park, K.-H., \& Kang, W.-W. (2018). Optimasi Proses Pembuatan Tepung Labu Kuning Menggunakan Response Surface Methodology Untuk Meningkatkan
Antioksidannya. Jurnal Teknologi Dan Industri Pangan, 29(1), 29-38. https://doi.org/10.6066/jtip.2018.29.1.2 $\underline{9}$

Wahyono, A., Yudiastuti, S., \& Subaktilah, Y. (2020). Formulasi Tepung Premix Brownies Kukus Instan Labu Kuning (Patent No. S00202006225). Silvia Oktavia Nur Yudiastuti (silvia.oktavia@polije.ac.id).

Yudiastuti, S., Wahyono, A., \& Subaktilah, Y. (2021). Brownies Kukus Labu Kuning. Nasya Expanding Management.

Cc) (D) () $(2021$ by the authors. Submitted for cc) under the terms and conditions of the Creative Commons Attribution (CC BY SA) license (https://creativecommons.org/licenses/by-sa/4.0/). 